\title{
Article \\ Starch Production in Chlamydomonas reinhardtii through Supraoptimal Temperature in a Pilot-Scale Photobioreactor
}

\author{
Ivan N. Ivanov ${ }^{1,2}$, Vilém Zachleder ${ }^{1}$, Milada Vítová ${ }^{1} \mathbb{D}$, Maria J. Barbosa ${ }^{3}$ and Kateřina Bišová ${ }^{1, *(D)}$ \\ 1 Laboratory of Cell Cycles of Algae, Centre Algatech, Institute of Microbiology of the Czech Academy of \\ Sciences, 37981 Třeboň, Czech Republic; ivanov@alga.cz (I.N.I.); zachleder@alga.cz (V.Z.); \\ vitova@alga.cz (M.V.) \\ 2 Faculty of Science, University of South Bohemia, Branišovská 1760, 37005 České Budějovice, Czech Republic \\ 3 Bioprocess Engineering Group, AlgaePARC, Wageningen University \& Research, P.O. Box 16, \\ 6700 AA Wageningen, The Netherlands; maria.barbosa@wur.nl \\ * Correspondence: bisova@alga.cz; Tel.: +420-384-340-485
}

Citation: Ivanov, I.N.; Zachleder, V.; Vítová, M.; Barbosa, M.J.; Bišová, K. Starch Production in Chlamydomonas reinhardtii through Supraoptimal Temperature in a Pilot-Scale Photobioreactor. Cells 2021, 10, 1084. https://doi.org/10.3390/cells 10051084

Academic Editor: Suleyman

Allakhverdiev

Received: 6 April 2021

Accepted: 29 April 2021

Published: 1 May 2021

Publisher's Note: MDPI stays neutral with regard to jurisdictional claims in published maps and institutional affiliations.

Copyright: (C) 2021 by the authors. Licensee MDPI, Basel, Switzerland. This article is an open access article distributed under the terms and conditions of the Creative Commons Attribution (CC BY) license (https:/ / creativecommons.org/licenses/by/ $4.0 /)$.

\begin{abstract}
An increase in temperature can have a profound effect on the cell cycle and cell division in green algae, whereas growth and the synthesis of energy storage compounds are less influenced. In Chlamydomonas reinhardtii, laboratory experiments have shown that exposure to a supraoptimal temperature $\left(39^{\circ} \mathrm{C}\right)$ causes a complete block of nuclear and cellular division accompanied by an increased accumulation of starch. In this work we explore the potential of supraoptimal temperature as a method to promote starch production in C. reinhardtii in a pilot-scale photobioreactor. The method was successfully applied and resulted in an almost 3-fold increase in the starch content of C. reinhardtii dry matter. Moreover, a maximum starch content at the supraoptimal temperature was reached within 1-2 days, compared with 5 days for the control culture at the optimal temperature $\left(30^{\circ} \mathrm{C}\right)$. Therefore, supraoptimal temperature treatment promotes rapid starch accumulation and suggests a viable alternative to other starch-inducing methods, such as nutrient depletion. Nevertheless, technical challenges, such as bioreactor design and light availability within the culture, still need to be dealt with.
\end{abstract}

Keywords: microalgae; Chlamydomonas reinhardtii; starch; supraoptimal temperature; cell cycle; pilot-scale production

\section{Introduction}

Together with light and nutrient availability, temperature is one of the major abiotic factors affecting growth of microalgae [1-4]. Temperature has been found to affect individual metabolic processes in various ways. Cell division and the duration of the cell cycle are particularly susceptible to changes in temperature while other parts of cellular metabolism, such as growth and other related synthetic processes, appear to be less influenced by such changes $[5,6]$.

In green algae dividing by multiple fission, a gradual increase in temperature results in a physiological response in which cells at first increase their growth rate and shorten their cell cycle. Upon a further increase in temperature, an optimal point is reached at which growth rate is at its maximum and cell cycle duration is at its minimum. However, after exceeding this optimal temperature, the duration of the cell cycle is gradually prolonged while growth rates remain unaffected [1]. Eventually, after reaching a certain temperature (hereafter referred to as supraoptimal), the cell cycle is completely blocked while growth and metabolism remain seemingly further unaffected $[1,6]$. This effect of supraoptimal temperature was first observed in the 1960s and 1970s during small-scale laboratory experiments conducted with Chlorella sp. (Chlorophyta) [6-9]. It was determined that the specific supraoptimal temperature that causes cell cycle arrest varies between species of microalgae and must be controlled within a very narrow range. Otherwise, the cells will 
not achieve cell cycle arrest (at a temperature lower than supraoptimal) or will have their metabolism strongly affected which might lead to cell death (at a temperature higher than supraoptimal) [6].

An inherent property of cell division is that it is an energy-demanding process, consuming the majority of the cell's energy reserves [10]. A simple block of cell division leads to accumulation of starch and/or lipids in microalgal cultures grown in nitrogen (and other nutrient) starvation or limiting conditions [11-15]. A combination of cell cycle arrest and unaltered growth metabolism, as is the case of supraoptimal temperature treatment, leads to the build-up of surplus energy reserves [6,9]. For starch producing green algae, the accumulation of starch under supraoptimal temperature can be extensive and it can reach levels considerably higher than in cells cultivated at the optimal growth temperature and hence, it can be utilized as an approach to increase starch productivity.

Chlamydomonas reinhardtii has served as a well-established model for a number of years $[13,16]$. This green alga benefits from a wide array of readily available molecular tools for genetic engineering and strain optimization [16-18]. However, in spite of these benefits, the adoption of $C$. reinhardtii as a biotechnology platform has been limited. Only recently, attempts were made to increase the starch content of $C$. reinhardtii by utilizing techniques such as nutrient deprivation and temperature stress [6,10,13,19-22]. Although nutrient deprivation is an effective technique that can increase the starch content of $C$. reinhardtii to almost $49 \%(w / w)$, the build-up is rather slow and it can take weeks until the maximum concentration is reached, which reduces overall productivity [22]. In contrast, temperature stress can provide a rapid method for starch accumulation within short periods of time. In laboratory-scale experiments with synchronized cultures of $C$. reinhardtii, the cells at $30{ }^{\circ} \mathrm{C}$ initially accumulated starch as they grew in size, but this starch was spent for cell division. The cells at $39{ }^{\circ} \mathrm{C}$ grew in size similar to those at $30{ }^{\circ} \mathrm{C}$, but they did not divide. Instead, they continued to increase their cell size and after $24 \mathrm{~h}$, their total starch content was more than two-fold higher than the maximum at $30{ }^{\circ} \mathrm{C} \mathrm{[6]}$. Although promising, these results were obtained only under controlled laboratory conditions that utilized synchronized cultures with relatively low biomass densities and were exposed to abundant light intensities. Hence, the applicability of the supraoptimal temperature method for industrial production of starch is still largely unknown.

In the present study, we examine the potential for pilot-scale starch production in $C$. reinhardtii by supraoptimal temperature, a method that has already been proven to cause a rapid 2-fold increase in starch yields under laboratory conditions [6]. In doing so we investigate whether and how biomass density affects starch productivity, the possibility of culture recovery and reuse after the supraoptimal temperature treatment, as well as potential practical challenges and limitations of the method. To our knowledge, the experiments described here are the first attempt to employ supraoptimal temperature in the production of starch in microalgae at pilot-scale.

\section{Materials and Methods}

\subsection{Microorganism and Culturing Conditions}

The algal strain used in these experiments was the unicellular alga Chlamydomonas reinhardtii wild type 21gr (CC-1690), obtained from the Chlamydomonas Resource Center at the University of Minnesota (St. Paul, MN, USA). For routine subculturing, the strains were streaked onto culture plates containing standard high salt (HS) medium [23] solidified with agar every three weeks.

For the purpose of the experiments, a starting culture was cultivated in a bench-top flat-panel airlift photobioreactor (Algaemist, Technical Development Studio, Wageningen University, Wageningen, The Netherlands) in the following manner: $400 \mathrm{~mL}$ of liquid HS medium was inoculated directly from the culture plates and was cultivated at $30^{\circ} \mathrm{C}$ and under constant incident light intensity of $500 \mu \mathrm{mol}$ photons $\mathrm{m}^{-2} \mathrm{~s}^{-1}$ of photosynthetically active radiation (PAR) provided by light-emitting diode lamps (BXRA W1200, Bridgelux, Fremont, CA, USA). The cultures were aerated with a mixture of air and $\mathrm{CO}_{2}(2 \%, v / v)$ 
at a flow rate of $0.63 \mathrm{VVM}$ in order to provide a carbon source and mixing of the cell suspension.

\subsection{Culture Medium for the Pilot-Scale Cultivation}

All experiments were performed under photoautotrophic conditions. The culture medium used for the pilot-scale experiments was based on a HS medium but was modified in order to facilitate high biomass yields with the $\mathrm{NH}_{4} \mathrm{Cl}$ concentration being increased 5-fold. This resulted in a growth medium with the following final composition: $250 \mathrm{~g} \mathrm{~L}^{-1}$ $\mathrm{NH}_{4} \mathrm{Cl}, 2 \mathrm{CaCl}_{2} \cdot 2 \mathrm{H}_{2} \mathrm{O}, 20 \mathrm{~g} \mathrm{~L}^{-1} \mathrm{MgSO}_{4} \cdot 7 \mathrm{H}_{2} \mathrm{O}, 1.84 \mathrm{~g} \mathrm{~L}^{-1} \mathrm{C}_{10} \mathrm{H}_{12} \mathrm{FeN}_{2} \mathrm{NaO}_{8}, 0.05 \mathrm{~g} \mathrm{~L}^{-1}$ $\mathrm{Na}_{2} \mathrm{MoO}_{4} \cdot 2 \mathrm{H}_{2} \mathrm{O}, 3.09 \mathrm{~g} \mathrm{~L}^{-1} \mathrm{H}_{3} \mathrm{BO}_{3}, 1.18 \mathrm{~g} \mathrm{~L}^{-1} \mathrm{MnSO}_{4} \cdot 7 \mathrm{H}_{2} \mathrm{O}, 1.40 \mathrm{~g} \mathrm{~L}^{-1} \mathrm{CoSO}_{4} \cdot 7 \mathrm{H}_{2} \mathrm{O}$, $1.24 \mathrm{~g} \mathrm{~L}^{-1} \mathrm{CuSO}_{4} \cdot 5 \mathrm{H}_{2} \mathrm{O}, 1.43 \mathrm{~g} \mathrm{~L}^{-1} \mathrm{ZnSO}_{4} \cdot 7 \mathrm{H}_{2} \mathrm{O}, 72 \mathrm{~g} \mathrm{~L}^{-1} \mathrm{KH}_{2} \mathrm{PO}_{4}, 134 \mathrm{~g} \mathrm{~L}^{-1} \mathrm{~K}_{2} \mathrm{HPO}_{4}$. For the preparation of the medium, $100 \times$ concentrated stock solutions of macro elements and microelements were used. All components, excluding phosphates, were diluted in distilled $\mathrm{H}_{2} \mathrm{O}$ and autoclaved for $20 \mathrm{~min}$ at $121^{\circ} \mathrm{C}$. After cooling, the sterile autoclaved phosphates were added. The medium used for cultivation in the pilot-scale flat-panel photobioreactor was not sterilized and tap water was used to dilute the stock solutions. In the course of the experiments, $\mathrm{pH}$ was monitored daily and was maintained at $7.0 \pm 0.1$ by the addition of $2 \mathrm{M} \mathrm{NaOH}$. Foam formation in the reactor vessels was controlled with the help of $10 \times$ diluted antifoam silicone Snapsil RE 20 containing 30\% active compound (Product code: 84538.290, VWR International, LLC, Radnor, PA, USA).

\subsection{Pilot-Scale Flat-Panel Photobioreactor}

A flat-panel Algae-Germ photobioreactor with two cultivation vessels, each of a total volume of $25 \mathrm{~L}$ (20 L of culture volume) (Figure 1), was used in all experiments described here. The photobioreactor was situated at $51^{\circ} 59^{\prime} 45.6^{\prime \prime} \mathrm{N}, 5^{\circ} 39^{\prime} 25.7^{\prime \prime} \mathrm{E}$ in Wageningen, Netherlands and was placed within a greenhouse with panels facing $240^{\circ} \mathrm{SW}$. Each of the cultivation vessels had the following dimensions: length: $70 \mathrm{~cm}$, height: $72 \mathrm{~cm}$, width (optical path: $5 \mathrm{~cm}$ ). Cooling and heating of the microalgal suspension culture was provided by two refrigerating/heating circulators (Julabo GmbH, Seelbach, Germany) that circulated water through temperature control coils, which were submerged in the culture suspension. A simple aeration system provided a constant flow of a mixture of air and $\mathrm{CO}_{2}(2 \%, v / v)$ and ensured mixing of the suspension culture. Both cultivation vessels were constantly illuminated by a panel of luminescent lamps (Master TL-D 58W /840, Philips, Amsterdam, the Netherlands) delivering $50 \mu \mathrm{mol}$ photons $\mathrm{m}^{-2} \mathrm{~s}^{-1}$ of PAR (measured at the vessel surface). However, the majority of PAR delivered to the cultures was through exposure to natural sunlight.
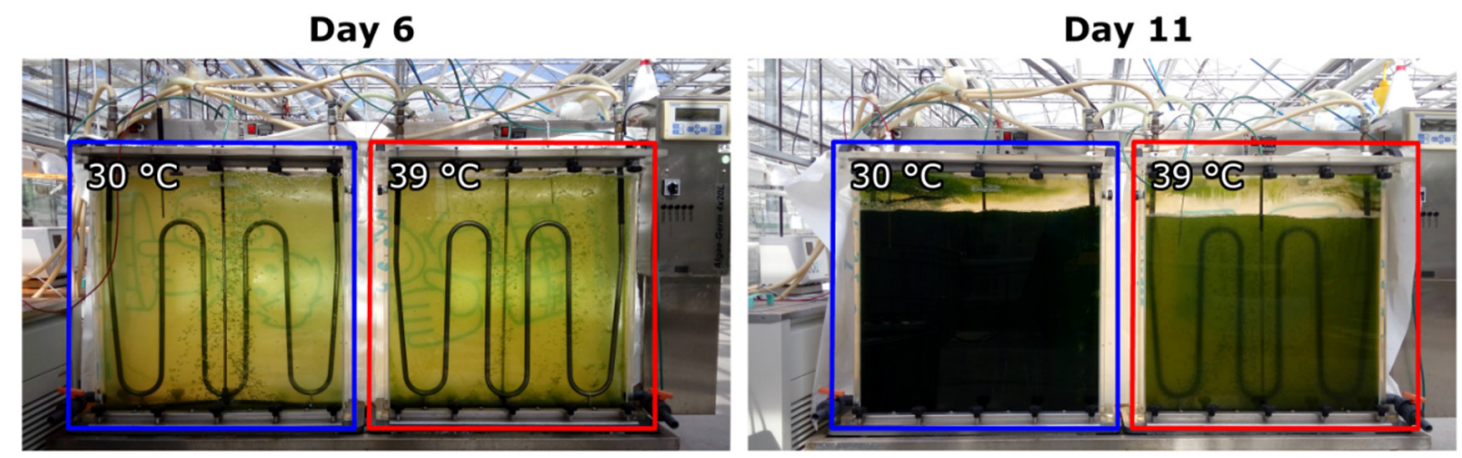

Figure 1. Changes of optical densities of $C$. reinhardtii cultures starting at the same cell density (day 6 , left photobioreactor) and grown at the same light intensity for 5 days at temperatures of $30{ }^{\circ} \mathrm{C}$ and $39{ }^{\circ} \mathrm{C}$ (day 11 , right photobioreactor). For description of the photobioreactor see Materials and Methods in Section 2.3. 


\subsection{Experimental Approach}

All the experiments were performed in the time-span between July 17th and September 17th, 2018 (Table 1). Each experiment consisted of two phases. During the biomass accumulation phase, one cultivation vessel was filled with $20 \mathrm{~L}$ of HS medium and was inoculated with $0.8 \mathrm{~L}$ of starting inoculum of cell concentration approximately $3.5 \times 10^{7}$ cells $\mathrm{mL}^{-1}$. The resulting culture, with an initial cell concentration of approximately $1.4 \times 10^{6}$ cells mL ${ }^{-1}$, was then incubated at $30^{\circ} \mathrm{C}$ for 4 to 6 days. The supraoptimal temperature phase started upon reaching a biomass concentration exceeding $1.0 \mathrm{~g} \mathrm{~L}^{-1}$. At this point the culture was diluted with HS medium and was separated into two cultivation vessels, which were then transferred to $30^{\circ} \mathrm{C}$ or $39^{\circ} \mathrm{C}$.

Table 1. Overview of the experiments performed including date and duration. Temperature and initial biomass concentration after dilution of the culture from the biomass accumulation phase are shown. All experiments were performed in the summer of 2018.

\begin{tabular}{|c|c|c|c|}
\hline Experiment Date & Total Duration (days) & Temperature Treatment $\left({ }^{\circ} \mathrm{C}\right)$ & $\begin{array}{l}\text { DM at the Beginning of } \\
\text { Experiment }\left(\mathrm{g} \mathrm{L}^{-1}\right)\end{array}$ \\
\hline \multirow{2}{*}{$17.07-31.07$} & \multirow{2}{*}{14} & 39 & 0.2 \\
\hline & & 39 & 0.8 \\
\hline \multirow{2}{*}{$13.08-23.08$} & \multirow{2}{*}{10} & 39 & 0.1 \\
\hline & & 39 & 0.2 \\
\hline \multirow{2}{*}{$23.08-03.09$} & \multirow{2}{*}{11} & 39 & 0.1 \\
\hline & & 39 & 0.8 \\
\hline \multirow{2}{*}{ 03.09-17.09 } & \multirow{2}{*}{12} & 30 & 0.1 \\
\hline & & 39 & 0.1 \\
\hline
\end{tabular}

\subsection{Light Measurements}

The photon flux density (Iph, $\mu$ mol photons $\mathrm{m}^{-2} \mathrm{~s}^{-1}$ ) was measured with a LI-COR 190-SA $2 \pi$ PAR (400-700 nm) quantum sensor (LiCor, Lincoln, NE, USA). Continuous light data logging was made with a sensor from the same model and manufacturer, mounted outdoors and facing the sky, parallel to the ground.

To obtain a measure of light energy absorbed by the cell suspension grown at different concentrations of cells, the mean light intensity (I) was calculated according to the LambertBeer law:

$$
\mathrm{I}=\left(\mathrm{I}_{\mathrm{i}}-\mathrm{I}_{\mathrm{t}}\right) / \ln \left(\mathrm{I}_{\mathrm{i}} / \mathrm{I}_{\mathrm{t}}\right) \text {, }
$$

where $I_{i}$ is the incident light intensity at the surface of the culture vessel and $I_{t}$ is the transmitted light intensity measured at the rear side of the culture vessel. The mean light $\left(\mu \mathrm{mol}\right.$ cell $^{-1}$ ) was calculated by dividing the mean light intensity during $24 \mathrm{~h}$ (obtained by continuous light data logging) by the number of viable cells for that period.

\subsection{Cell Size and Cell Number Measurements}

One milliliter aliquots of culture suspension were taken, fixed with $10 \mu \mathrm{L}$ of iodine solution ( $1 \mathrm{~g} \mathrm{I}, 5 \mathrm{~g} \mathrm{KI}, 100 \mathrm{~mL} \mathrm{H}_{2} \mathrm{O}$ ), and stored at $4{ }^{\circ} \mathrm{C}$. Cell diameter was measured on microphotographs taken with an Olympus Camedia C-5050 Zoom digital camera. The microphotographs were then analyzed using Image image processing and analysis software (U. S. National Institute of Health, Rockville Pike, MD, USA). The cell diameter was recalculated to volume by a basic formula assuming a spherical cell shape. Cell number was determined by means of a Bürker counting chamber (Meopta, Prerov, Czech Republic).

\subsection{Dry Matter Measurements}

Aliquots of culture suspension $(50 \mathrm{~mL})$ were taken and centrifuged (1580R, Labogene ApS, Lillerød, Denmark) for $10 \mathrm{~min}$ at $4000 \mathrm{rpm}$. The supernatant was then removed, and the remaining pellet was transferred to a $2 \mathrm{~mL}$ preweighed test tube and dried for $24 \mathrm{~h}$ at $105^{\circ} \mathrm{C}$. After cooling for $2 \mathrm{~h}$, the test tube with the pellet was weighed on an analytical 
balance (CP224S-OCE, Sartorius AG, Göttingen, Germany) and the weight of the pellet was determined by subtracting the weight of the empty test tube.

\subsection{Starch Analysis}

A starch-specific enzymatic method was used to accurately estimate the biomass starch content. Aliquots of culture suspension $(10 \mathrm{~mL})$ were harvested and centrifuged (1580R, Labogene ApS, Lillerød, Denmark) for $10 \mathrm{~min}$ at $4000 \mathrm{rpm}$. The supernatant was then discarded, and the resulting pellets were stored at $-20^{\circ} \mathrm{C}$. After thawing, the cells in the pellets were disintegrated by adding $300 \mu \mathrm{L}$ of glass beads $(0.7 \mathrm{~mm}$ in diameter) and vortexing vigorously (MS3, IKA-Werke GmbH \& Co. KG, Staufen, Germany) for $15 \mathrm{~min}$. Depigmentation of the samples was carried out by adding $1 \mathrm{~mL}$ of $80 \%(v / v)$ ethanol to the pellet and incubating in a water bath for $15 \mathrm{~min}$ at $68^{\circ} \mathrm{C}$ after which the samples were centrifuged (1580R, Labogene ApS, Lillerød, Denmark) for 2 min at 14,000 rpm and the supernatant was removed. The depigmentation procedure was repeated 3 to 4 times (or until the pellet was completely discolored). After that, $1 \mathrm{~mL}$ of $\alpha$-amylase (porcine pancreas, Sigma-Aldrich, St. Louis, MO, USA) solution $\left(0.5 \mathrm{~g} \cdot \mathrm{L}^{-1} w / v\right.$ in $0.1 \mathrm{M}$ sodium phosphate buffer ( $\mathrm{pH}$ 6.9)) was added to the samples and incubated for $1 \mathrm{~h}$ at $37^{\circ} \mathrm{C}$. The samples were centrifuged (1580R, Labogene ApS, Lillerød, Denmark) for $2 \mathrm{~min}$ at $14,000 \mathrm{rpm}$, after which the supernatant was used for the quantification of reducing sugars through the dinitrosalicylic acid (DNSA) color reaction, as described by Miller [24]. Briefly, $500 \mu \mathrm{L}$ of supernatant were mixed with $500 \mu \mathrm{L}$ DNSA solution (1\% (w/v) DNSA, 30\% $(w / v)$ potassium sodium tartrate tetrahydrate, $20 \%(v / v) 2 \mathrm{M}$ sodium hydroxide) and incubated for $5 \mathrm{~min}$ at $105{ }^{\circ} \mathrm{C}$ on a heat block. Following a cooling period of $10 \mathrm{~min}$ at room temperature the mixture was diluted five-fold with distilled water, after which the absorbance of the samples was measured at $570 \mathrm{~nm}$. The concentration of starch was estimated through a calibration curve of potato starch (Lach-Ner s.r.o., Neratovice, Czech Republic) digested with $\alpha$-amylase.

\subsection{Microscopic Observations and Starch Staining}

Microscopic observations during the course of the experiments were carried out daily on a Leica Laborlux S microscope. Staining of starch was with the same iodine solution that was used for fixing cell counting samples in a 1:10 volume ratio of staining solution to sample.

\section{Results}

Starch accumulation in C. reinhardtii can be induced by nutrient depletion [12,13,22]. In order to exclude such effect, a biomass accumulation phase in fully supplemented medium at the optimal temperature was included prior to the supraoptimal temperature phase. The purpose of the biomass accumulation phase was to demonstrate that the cultures were not limited by nutrients and to estimate the typical starch content in C. reinhardtii cultures during exponential growth under the optimal growth temperature. Please, refer to Table 1 for an overview of the time span of the experiments as well as combinations of biomass densities and temperature treatments applied.

\subsection{The Effects of Supraoptimal Temperature}

To assess the effects of supraoptimal temperature on cell growth and division, as well as starch accumulation, the culture behavior at two parallel treatments of $30^{\circ} \mathrm{C}$ (control) and $39{ }^{\circ} \mathrm{C}$ was compared. At first a C. reinhardtii culture was cultivated at $30^{\circ} \mathrm{C}$ for 6 days. After reaching a biomass concentration of $1.0 \mathrm{~g} \mathrm{~L}^{-1}$, the culture was diluted with $\mathrm{HS}$ medium to $0.1 \mathrm{~g} \mathrm{~L}^{-1}$ and split into two cultures which were then cultivated at $30^{\circ} \mathrm{C}$ and $39^{\circ} \mathrm{C}$, respectively (Figure 1 ).

The control culture cultivated at $30^{\circ} \mathrm{C}$ had a similar pattern of biomass accumulation to that before dilution and returned to the pre-dilution biomass concentration within 6 days (reaching a maximum of nearly $1 \mathrm{~g} \mathrm{~L}^{-1}$ ) (Figure 2A). In contrast, biomass accumulation 
of the culture at $39^{\circ} \mathrm{C}$ stopped after 2 days, reaching a maximum of only $0.4 \mathrm{~g} \mathrm{~L}^{-1}$. The biomass starch content in terms of percentage of starch within the dry matter (DM) was much greater in the culture cultivated at $39^{\circ} \mathrm{C}$, reaching $18 \%$ of DM as opposed to $8 \%$ of $\mathrm{DM}$ at $30^{\circ} \mathrm{C}$ (Figure 2C). Moreover, the volumetric starch concentration in $\mathrm{mg} \mathrm{mL}^{-1}$ was faster in the culture cultivated at $39^{\circ} \mathrm{C}$, reaching a maximum of $0.07 \mathrm{~g} \mathrm{~L}^{-1}$ in only 2 days as opposed to 5 days and $0.06 \mathrm{~g} \mathrm{~L}^{-1}$ in the culture cultivated at $30^{\circ} \mathrm{C}$ (Figure 2D).
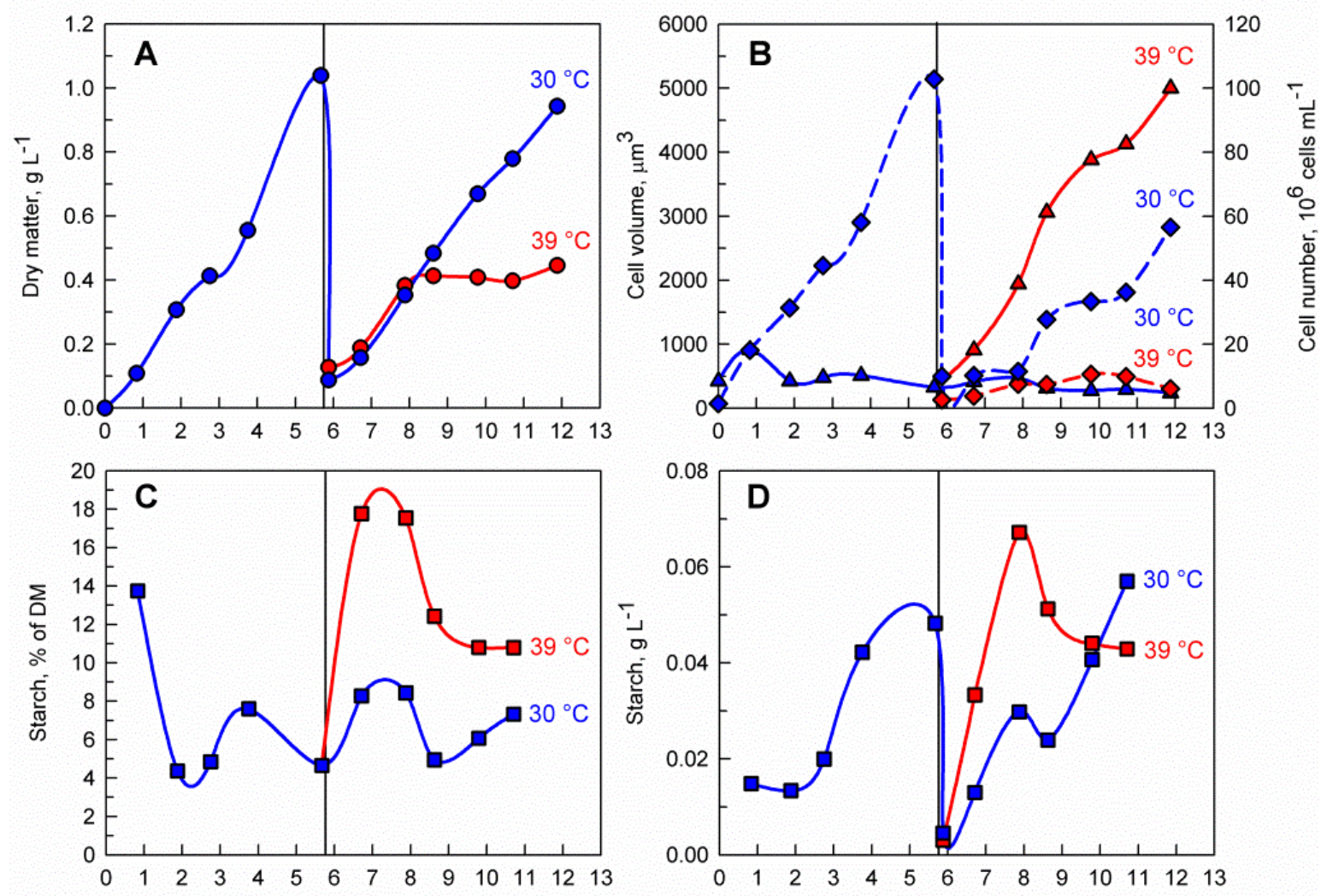

Time, days

Figure 2. Effect of supraoptimal temperature on dry matter accumulation (A), average cell volume (solid line, triangles) and cell number (dashed line, diamonds) (B), biomass starch content (C) and volumetric starch concentration in the culture (D). The vertical line on day 6 represents the shift from biomass accumulation phase to supraoptimal temperature phase. Blue lines represent cultivation at $30^{\circ} \mathrm{C}$ while red lines represent cultivation at $39^{\circ} \mathrm{C}$. During the biomass accumulation phase a single $C$. reinhardtii culture was cultivated at $30^{\circ} \mathrm{C}$. After 6 days the culture was diluted to a biomass concentration of $0.1 \mathrm{~g} \mathrm{~L}^{-1}$ and divided into two separated cultures. One of the cultures was cultivated at $39^{\circ} \mathrm{C}$ (supraoptimal temperature treatment) while the other one was cultivated at $30{ }^{\circ} \mathrm{C}$ (control). Panel B represents the median volume of cells and an estimation of the mean cell number within a defined volume of culture suspension.

Microscopic observations of the culture cultivated at $30^{\circ} \mathrm{C}$ did not reveal any change in the pattern of cell division with cells having a median cell volume of $422 \mu \mathrm{m}^{3}$ and cell division occurring, as expected, during the course of the experiment with mother cells dividing predominantly into eight daughter cells (Figures 2B and 3). In contrast, the cells transferred to $39^{\circ} \mathrm{C}$ largely stopped dividing and the few dividing cells formed mostly two or four daughter cells. The inhibition of cell division was also reflected in the median cell volume, which increased eight-fold at $39^{\circ} \mathrm{C}$ reaching $3479 \mu \mathrm{m}^{3}$. 
Day 7

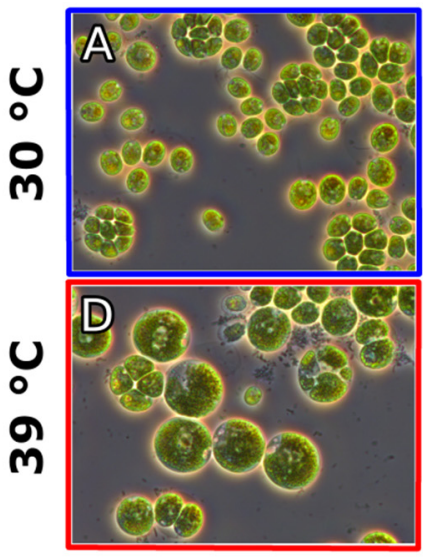

Day 9

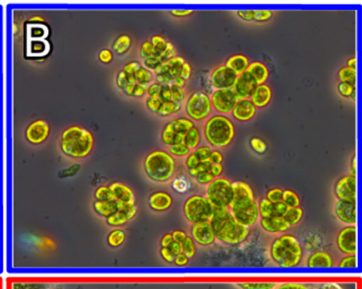

Day 11

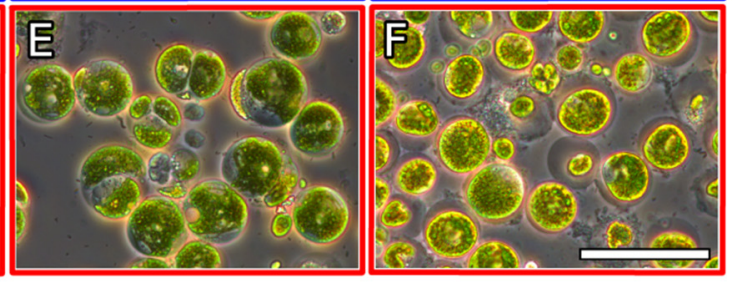

Figure 3. Effect of supraoptimal temperature on the cell division pattern and cell size in C. reinhardtii. The algal culture was cultivated for 6 days at $30^{\circ} \mathrm{C}$ after which it was split, transferred to $30{ }^{\circ} \mathrm{C}$ (A-C) and $39^{\circ} \mathrm{C}(\mathbf{D}-\mathbf{F})$ and monitored for another 5 days. Day 7 corresponds to the first day after the split. Size of bar: $50 \mu \mathrm{m}$.

\subsection{The Effects of Biomass Density}

Light availability within the culture suspension itself is a function of biomass density and incident light intensity. To study the effect of light availability on starch accumulation at a supraoptimal temperature, two parallel cultures of different biomass concentrations and identical incident light intensity were compared. To do so, a C. reinhardtii culture was cultivated at $30^{\circ} \mathrm{C}$ for 6 days. After reaching a biomass concentration of $1.5 \mathrm{~g} \mathrm{~L}^{-1}$ the culture was diluted with a HS medium to avoid nutrient limitation and split into two cultures, with an initial biomass concentration of $0.2 \mathrm{~g} \mathrm{~L}^{-1}$ (less dense culture) and $0.8 \mathrm{~g} \mathrm{~L}^{-1}$ (dense culture); these were then cultivated at $39^{\circ} \mathrm{C}$ for 8 more days (Figure $4 \mathrm{~A}$ ). During the first three days after dilution and transfer to $39^{\circ} \mathrm{C}$, both cultures increased in biomass and reached a maximum of $0.6 \mathrm{~g} \mathrm{~L}^{-1}$ and $1.1 \mathrm{~g} \mathrm{~L}^{-1}$, respectively. After this, the biomass concentration in the less dense culture remained constant while the biomass in the dense culture started to decline rapidly. The difference in biomass concentrations was also reflected in the mean light availability in the cultures, with the cells in the less dense culture being exposed to notably more light than the ones in the dense culture (Figure 4B). The increase in biomass relative starch content was remarkably rapid and was much more pronounced in the less dense culture, reaching a maximum of $13.2 \%$ of DM within the first day of the transfer to $39^{\circ} \mathrm{C}$ (Figure 4C). This rapid 3-fold increase from the initial culture represents a striking contrast to the starch values within the dense culture, which did not increase when compared to the pre-treatment phase. When comparing the different biomass concentrations in the cultures, the volumetric starch concentration $\left(\mathrm{g} \mathrm{L}^{-1}\right)$ in the less dense culture was about $20 \%$ higher than in the dense culture. However, the maximum volumetric starch concentration reached at $39^{\circ} \mathrm{C}$ was similar (in the case of the less dense culture) or lower (in the case of the dense culture) than that reached during the biomass accumulation phase at $30^{\circ} \mathrm{C}$ (Figure 4D). Similar experiments with similar results were also performed at two lower initial cell densities in $39^{\circ} \mathrm{C}, 0.1 \mathrm{~g} \mathrm{~L}^{-1}$ and $0.2 \mathrm{~g} \mathrm{~L}^{-1}$ (Figure S1). 

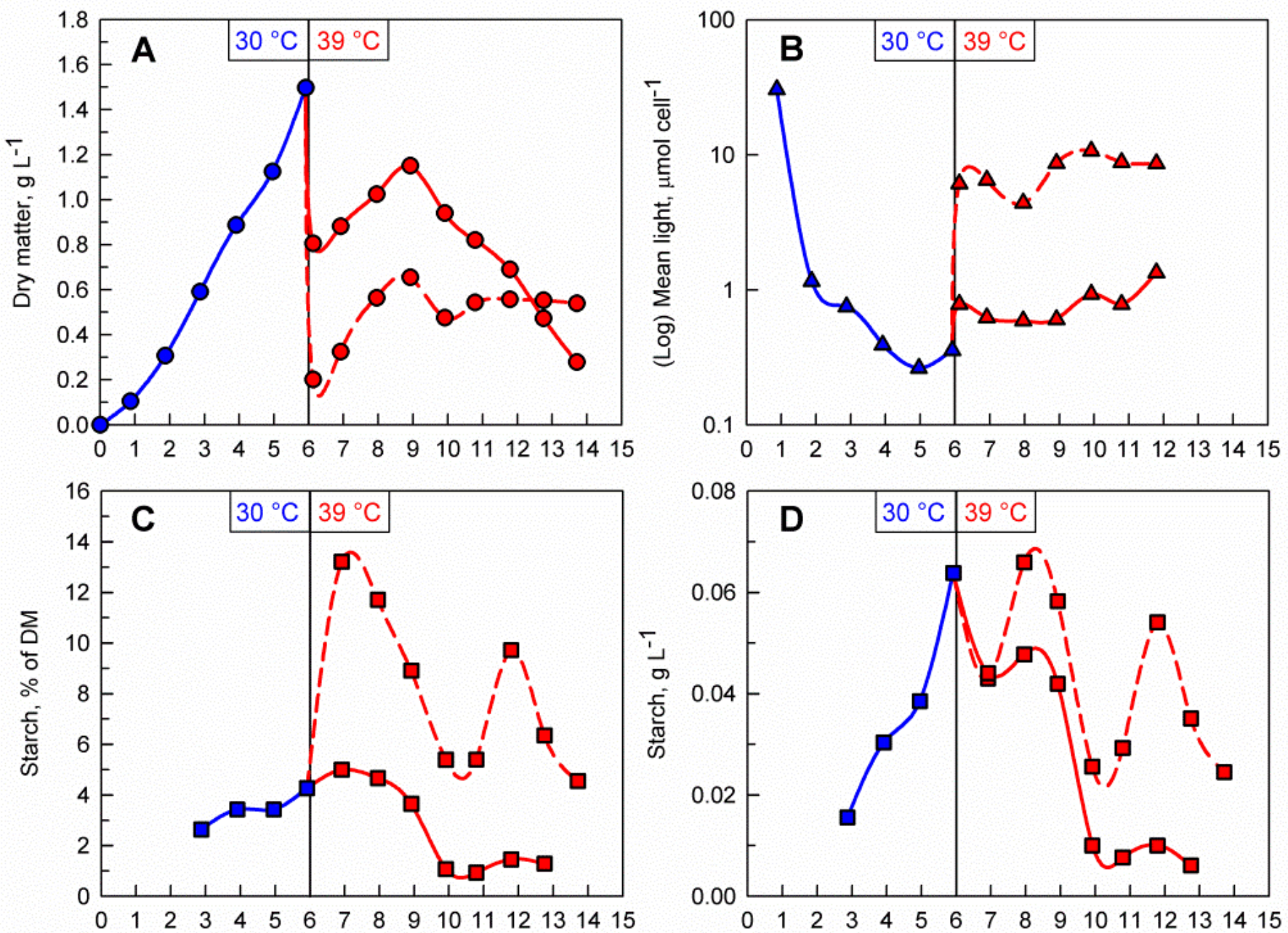

Time, days

Figure 4. Effect of different biomass concentrations at the supraoptimal temperature on the time course of dry matter accumulation (A), mean light availability (B), biomass starch content (C), and volumetric starch concentration (D) in the culture. The vertical line at day 6 represents the shift between biomass accumulation and supraoptimal temperature phases. Blue lines and markers indicate cultivation at $30^{\circ} \mathrm{C}$ and red lines and markers indicate cultivation at $39^{\circ} \mathrm{C}$. During the biomass accumulation phase a single $C$. reinhardtii culture was cultivated at $30^{\circ} \mathrm{C}$. After 6 days, the culture was split into two and diluted to $0.2 \mathrm{~g} \mathrm{~L}^{-1}$ (dashed red line) and $0.8 \mathrm{~g} \mathrm{~L}^{-1}$ (solid red line) then transferred to $39^{\circ} \mathrm{C}$.

\subsection{Transfer Back to Optimal Temperature}

As previously demonstrated, the supraoptimal temperature treatment allows rapid accumulation of starch, during which time, the maximum biomass starch content is reached rapidly within 1 to 2 days. However, due to the nature of the temperature block on cell division, a biomass accumulation phase is required before the treatment can be applied. Thus, a possible starch production process on an industrial scale will involve a repeatedbatch culture which is treated with consecutive alterations of temperature between 30 and $39^{\circ} \mathrm{C}$. To investigate whether the cells are viable, and their cell cycle block can recover after the supraoptimal temperature phase, the $\mathrm{C}$. reinhardtii culture was cultivated at $30^{\circ} \mathrm{C}$ for 4 days. After reaching a biomass concentration of $1.2 \mathrm{~g} \mathrm{~L}^{-1}$, the culture was diluted with a HS medium and split into two cultures with initial biomass concentrations of $0.1 \mathrm{~g} \mathrm{~L}^{-1}$ and $0.8 \mathrm{~g} \mathrm{~L}^{-1}$, respectively (Figure $5 \mathrm{~A}$ ). Immediately after dilution, both cultures were transferred to $39^{\circ} \mathrm{C}$ for a period of three days. During the transfer to supraoptimal temperature, biomass accumulation in both cultures decreased with the decrease being much more pronounced in the $0.8 \mathrm{~g} \mathrm{~L}^{-1}$ culture. When the culture was moved back to 
$30^{\circ} \mathrm{C}$, biomass accumulation resumed in the $0.1 \mathrm{~g} \mathrm{~L}^{-1}$ culture while in the $0.8 \mathrm{~g} \mathrm{~L}^{-1}$ culture, biomass concentrations declined gradually. The difference in initial biomass concentration after dilution was also reflected in the mean light availability in the cultures, with the cells in the less dense culture being exposed to notably more light than the ones in the dense culture (Figure 5B). Starch synthesis was much more pronounced in the $0.1 \mathrm{~g} \mathrm{~L}^{-1}$ culture with biomass starch content increasing 4-fold and reaching nearly $20 \%$ of DM within the first day of transfer to supraoptimal temperature (compared to only $8 \%$ of DM in the $0.8 \mathrm{~g} \mathrm{~L}^{-1}$ culture) (Figure 5C). Although the biomass starch content in terms of percent of DM was higher in the $0.1 \mathrm{~g} \mathrm{~L}^{-1}$ culture, the volumetric starch concentration $\left(\mathrm{g} \mathrm{L}^{-1}\right)$ in both cultures was nearly identical due to the difference in biomass concentrations within the two cultures (Figure 5D).
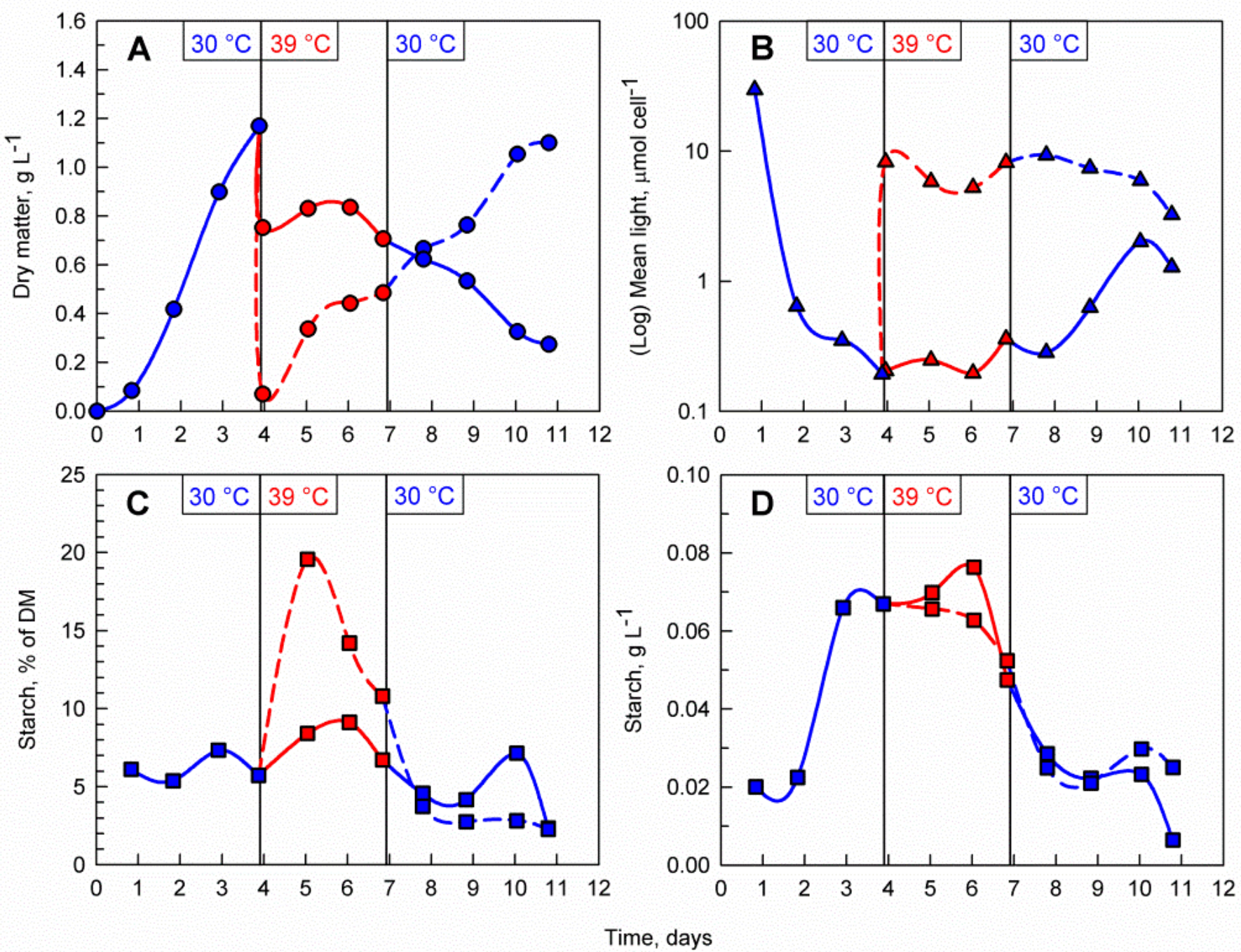

Figure 5. Effect of the combination of temperature shifts and different biomass concentrations on the course of dry matter accumulation (A), mean light availability (B), biomass starch content (C), volumetric starch concentration in the culture (D). A single C. reinhardtii culture was cultivated at $30^{\circ} \mathrm{C}$. After 4 days the culture was split into two, transferred to $39^{\circ} \mathrm{C}$ and diluted to $0.1 \mathrm{mg} \mathrm{mL}^{-1}$ (dashed red lines) and $0.8 \mathrm{mg} \mathrm{mL}^{-1}$ (solid red lines), respectively. At day 7, the $0.1 \mathrm{mg} \mathrm{mL}^{-1} \mathrm{culture}^{\circ}$ (dashed blue lines) and the $0.8 \mathrm{mg} \mathrm{mL}^{-1}$ culture (solid blue line) were transferred to $30^{\circ} \mathrm{C}$. Vertical lines at days 4 and 7 indicate those shifts in temperature (from $30^{\circ} \mathrm{C}$ to $39^{\circ} \mathrm{C}$ on day 4 and from $39{ }^{\circ} \mathrm{C}$ to $30^{\circ} \mathrm{C}$ on day 7 ).

Microscopic observations and analysis of the cell cycle confirmed that $C$. reinhardtii cells were dividing during the biomass accumulation phase at $30^{\circ} \mathrm{C}$ (Figure $6 \mathrm{~A}$ ) and transfer to supraoptimal temperature resulted in a block of cell division (Figure 6B,C,E,F). The cells in the $0.1 \mathrm{~g} \mathrm{~L}^{-1}$ culture were larger and rounder as opposed to cells in the $0.8 \mathrm{~g} \mathrm{~L}^{-1}$ 
culture, which were smaller (Figure 6B,E). Staining with iodine revealed the presence of large amounts of starch granules in the chloroplasts of the cells in both cultures one day after the transfer (Figure 6C,F). Upon transfer back to $30^{\circ} \mathrm{C}$ cell cycle progression was restored in the $0.1 \mathrm{~g} \mathrm{~L}^{-1}$ culture within one day (Figure 6D) as opposed to the cells in the $0.8 \mathrm{~g} \mathrm{~L}^{-1}$ which did not recover (Figure 6G).

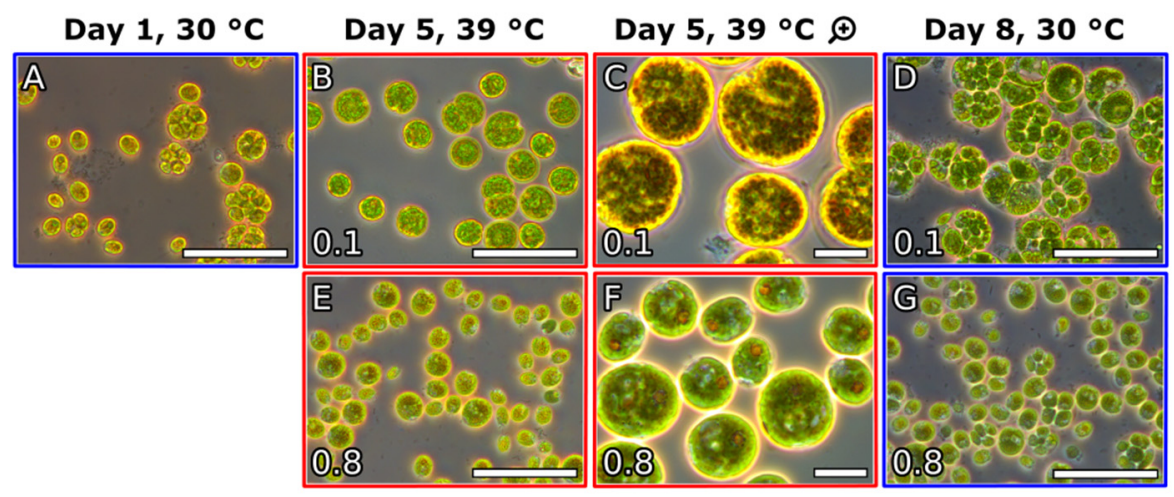

Figure 6. Microscopic observations. (A): Cells during day one of the biomass accumulation phase at $30{ }^{\circ} \mathrm{C}$. (B,E): Cells one day after transfer to $39^{\circ} \mathrm{C}$ and dilution to $0.1 \mathrm{~g} \mathrm{~L}^{-1}$ and $0.8 \mathrm{~g} \mathrm{~L}^{-1}$, respectively. $(\mathbf{C}, \mathbf{F})$ : magnification and iodine staining of starch granules in the cells from panels $(\mathbf{B}, \mathbf{E})$, respectively. $(\mathrm{D}, \mathrm{G})$ : cells one day after transfer back to $30^{\circ} \mathrm{C}$ of the cultures originally diluted to $0.1 \mathrm{~g} \mathrm{~L}^{-1}$ and $0.8 \mathrm{~g} \mathrm{~L}^{-1}$. Size of bar on panels (A,B,D,E,G): $50 \mu \mathrm{m}$, panels (C,F): $10 \mu \mathrm{m}$.

\section{Discussion}

\subsection{Effects of Supraoptimal Temperature on Starch Accumulation in C. reinhardtii at Pilot-Scale}

The transfer of $C$. reinhardtii cultures from optimal to supraoptimal temperature proved to have a pronounced effect on both cell cycle progression and the accumulation of energy reserves in the form of starch. Upon $39{ }^{\circ} \mathrm{C}$ treatment, cell division was inhibited, mean cell size was increased, and the biomass starch content was enhanced more than 2-fold (Figures 2C, 4C, and 5C, Figure S1C and Table 2). These observations are in agreement with results from supraoptimal temperature experiments conducted with synchronized cultures of C. reinhardtii in laboratory-scale experiments [6] and resemble the effect of supraoptimal temperature on Chlorella sp. [7,8]. The increase in starch as an energy storage molecule during a period of inhibited cell division supports the inverse relationship between chemical energy storage and energy expenditure for the normal operation of the cell cycle under optimal growth conditions. Increased starch accumulation in green algae is often linked to a block in the cell cycle. It was observed not only as an effect of supraoptimal temperature treatment but also as a response to nutrient deprivation $[13,20,22,25,26]$ and for cell cycle gene mutants [10]. The starch (over)accumulation is genetically linked to mutations in phosphoglucomutase 1, an enzyme involved in both glycolysis and starch biosynthesis [19]. Furthermore, C. reinhardtii mutants in DYRK kinase were shown to hyper-accumulate both starch and oil [21].

Table 2. Comparison of the effect of supraoptimal temperature in combination with various initial biomass concentrations on the maximum biomass starch content and the time when the maximum volumetric starch concentration was attained.

\begin{tabular}{cccc}
\hline $\begin{array}{c}\text { Initial DM } \\
\left(\mathbf{g ~ L ~ L ~}^{-1}\right)\end{array}$ & $\begin{array}{c}\text { Temperature } \\
\left({ }^{\circ} \mathbf{C}\right)\end{array}$ & $\begin{array}{c}\text { Max. Biomass Starch Content } \\
(\% \text { of DM) }\end{array}$ & $\begin{array}{c}\text { Max. Volumetric Starch } \\
\text { Concentration } \\
\left(\mathbf{g ~ L ~ L}^{-1}\right)\end{array}$ \\
\hline 0.1 & 39 & $21^{*}$ & $\begin{array}{c}\text { Time Required to Achieve Max. } \\
\text { Volumetric Starch Concentration } \\
(\mathbf{D a y s})\end{array}$ \\
0.2 & 39 & $14^{* *}$ & $0.067^{*}$ \\
0.8 & 39 & $7^{* *}$ & $0.069^{* *}$ \\
0.1 & 30 & 8 & $0.060^{* *}$ \\
\hline
\end{tabular}

* Shown value is an average of three cultivations; ** Shown value is an average of two cultivations. 
Starch synthesis in response to nitrogen depletion in laboratory-scale experiments with C. reinhardtii cultures has been reported to increase starch content to up to $70 \mu \mathrm{g}$ $10^{-6}$ cells (i.e., $70 \mathrm{pg} \mathrm{cell}^{-1}$ ). However, this type of treatment required 7 days of nitrogen starvation until the maximum starch content was reached [26]. Similarly, starch levels induced by sulfur depletion reached up to $49 \%$ of DM after 20 days. However, during the upscaling of the process, the maximum starch content which was reached was nearly twofold lower at around $25 \%$ of DM [22]. Thus, the results produced under stable laboratory conditions are often difficult to directly extrapolate to an industrial scale. This is also well documented on the comparison of starch production in supraoptimal temperature in laboratory conditions [6] and the results described here, i.e., $80 \mathrm{pg}^{\text {cell }}{ }^{-1}$ versus $16 \mathrm{pg}$ cell $^{-1}$. Notwithstanding, the limitation of pilot-scale cultivation, the starch accumulation in experiments presented here was significantly faster (only 1 to 2 days) compared to the nutrient limitation conditions $[22,26]$. Such a significant decrease in cultivation time might prove of notable importance for the economic viability of industrial-scale production of microalgal based starch.

\subsection{The Importance of Light Availability}

A modern biotechnological process requires high productivity and cost efficiency [27]. This can only be achieved through rapid accumulation and high volumetric concentrations of the desired product. In order for microalgal starch production to be economically viable, starch yields per volume of culture must be high. This is only possible through increased starch content per cell at high biomass concentrations. Yet, increase in biomass density led to a decrease in mean light availability within the culture (Figures 4B, 5B and Figure S1B). This is likely due to light scattering and self-shading of the microalgal cells which have been found to cause sharp reductions in light availability with depth [28-30]. This limited light availability within the culture led to a reduction in the starch content and ultimately limited the effectiveness of the supraoptimal temperature treatment (Table 2). Similarly, recent findings in Nannochloropsis sp. showed a strong link between photosynthetic efficiency and the accumulation rate of lipids which are the primary energy storage compound in this microalga [31]. As a result, although the supraoptimal treatment led to a more rapid accumulation of starch, the maximum volumetric starch concentration achieved during cultivation at $39^{\circ} \mathrm{C}$ did not show any notable increase over the maximum volumetric starch concentrations reached at $30^{\circ} \mathrm{C}$.

Furthermore, in the cultivation system used in this study, the combination of high cell density (leading to low light availability) and supraoptimal temperature seemed to have a negative effect on $C$. reinhardtii cultures after a certain period of time. In both cultivations at a starting biomass density of $0.8 \mathrm{mg} \mathrm{mL}^{-1}$, biomass decline was observed after 3 days of exposure to supraoptimal temperature (Figures $4 \mathrm{~A}$ and $5 \mathrm{~A}$ ), and the cultures did not recover when transferred to the optimal growth temperature (Figure 5A). In addition, light penetration into the high biomass cultures was further hindered by excessive biofilm formation (Figure S2).

When synthesis of a substance such as starch is linked to the photosynthetic capacity of the cell, and consequently to light availability, production in large-scale requires efficient utilization of light. In this regard, an effective reactor design that ensures proper light distribution within a high biomass culture is essential $[28,29,32]$. This can be achieved by decreasing the optical path that light has to travel within the culture and carefully controlling the biomass concentration at the time when supraoptimal temperature is applied.

\subsection{Perspectives}

The main advantage of the experiments presented here, compared to the other treatments, is the speed of starch accumulation (Table 2). In the context of large-scale cultivation of microalgae, short turnaround times are important not only because they allow for higher productivity but also because they reduce the risk of biological contamination by a compet- 
itive microalgal species or fortuitous grazers. This makes the supraoptimal temperature method a viable option for increasing starch productivity in microalgae.

Based on the results described here, a tentative industrial-scale starch production strategy based on the use of supraoptimal temperature can employ both batch and repeated batch modes of operation. This is made possible by the fact that the culture can be recovered and reused as an inoculum after the temperature treatment (Figures 5A and 6). The production flow can consist of alternating biomass accumulation (6-7 days) and temperature treatment phases (1-2 days). Moreover, large and heavy cells that are filled with starch should enable better downstream processing of the biomass. However, the economic viability of the process depends greatly on improving bioreactor design and reducing the associated energy and labor costs.

\section{Conclusions}

The method of supraoptimal temperature treatment was successfully applied in pilot-scale and resulted in a considerable, nearly 3-fold, enhancement of starch content in C. reinhardtii at low biomass densities. Moreover, starch synthesis was faster, with the maximum being reached within only 1-2 days, compared to five days at the optimal temperature. Thus, the supraoptimal temperature treatment provides a viable alternative to other starch stimulating methods, such as nutrient depletion. This is especially true when times required for starch accumulation are taken into account. However, technical challenges, such as bioreactor design and improved light availability per cell, still need to be dealt with.

Supplementary Materials: The following are available online at https://www.mdpi.com/article/ 10.3390/cells10051084/s1, Figure S1: Effect of the combination of supraoptimal temperature and different biomass concentrations (A) on \% of starch in the microalgal biomass (B), mean light availability (C) and starch concentration in the culture (D). Figure S2: Cultivation vessels where C. reinhardtii cultures treated at a supraoptimal temperature and with different starting biomass densities have been cultured.

Author Contributions: Conceptualization, K.B., M.J.B., V.Z. and M.V.; methodology, I.N.I.; validation, K.B., M.J.B., V.Z. and M.V.; formal analysis, I.N.I. and K.B.; investigation, I.N.I., M.V., V.Z., M.J.B. and K.B.; resources, V.Z., M.J.B. and K.B.; data curation, I.N.I., M.V., V.Z., M.J.B. and K.B.; writingoriginal draft preparation, I.N.I., V.Z. and K.B.; writing—review and editing, I.N.I., M.V., V.Z., M.J.B. and K.B.; visualization, I.N.I., M.V., V.Z. and K.B.; supervision, M.J.B. and K.B.; project administration, M.J.B. and K.B.; funding acquisition, M.J.B., K.B. and I.N.I. All authors have read and agreed to the published version of the manuscript.

Funding: This work was supported by the Czech Science Foundation (grant no. 15-09231S) and the Ministry of Education, Youth and Sports of the Czech Republic (project no. EF16_027/0007990).

Institutional Review Board Statement: Not applicable.

Informed Consent Statement: Not applicable.

Data Availability Statement: All data presented in this study are available within this article or Supplementary Materials. There are no special databases associated with this manuscript.

Acknowledgments: We would like to express our sincere gratitude to Rick Wieggers at AlgaeParc ${ }^{\mathrm{TM}}$ for his indispensable help in the organization of the experiments and the operation of the microalgae cultivation equipment. We also thank J. D. Brooker for critical reading and language editing of the text.

Conflicts of Interest: The authors declare no conflict of interest.

\section{References}

1. Vítová, M.; Bišová, K.; Hlavová, M.; Kawano, S.; Zachleder, V.; Čížková, M. Chlamydomonas reinhardtii: Duration of its cell cycle and phases at growth rates affected by temperature. Planta 2011, 234, 599-608. [CrossRef]

2. Vítová, M.; Bišová, K.; Umysová, D.; Hlavová, M.; Kawano, S.; Zachleder, V.; Čížková, M. Chlamydomonas reinhardtii: Duration of its cell cycle and phases at growth rates affected by light intensity. Planta 2011, 233, 75-86. [CrossRef] 
3. Ras, M.; Steyer, J.-P.; Bernard, O. Temperature effect on microalgae: A crucial factor for outdoor production. Rev. Environ. Sci. Biotechnol. 2013, 12, 153-164. [CrossRef]

4. Singh, S.P.; Singh, P. Effect of temperature and light on the growth of algae species: A review. Renew. Sustain. Energy Rev. 2015, 50, 431-444. [CrossRef]

5. Zachleder, V.; Ivanov, I.; Vítová, M.; Bišová, K. Effects of cyclin-dependent kinase activity on the coordination of growth and the cell cycle in green algae at different temperatures. J. Exp. Bot. 2019, 70, 845-858. [CrossRef]

6. Zachleder, V.; Ivanov, I.; Vítová, M.; Bišová, K. Cell cycle arrest by supraoptimal temperature in the alga Chlamydomonas reinhardtii. Cells 2019, 8, 1237. [CrossRef] [PubMed]

7. Semenenko, V.E.; Vladimirova, M.G.; Opleanskaja, O.B.; Raikov, N.I.; Kovanova, E.S. Physiological characteristics of Chlorella sp. K under conditions of high extremal temperatures II. Changes in biosynthesis, ultrastructure and activity of photosynthetic apparatus of Chlorella at uncoupling cellular functions at extreme temperature. Russian J. Plant Physiol. 1969, 16, 210-220.

8. Semenenko, V.E.; Vladimirova, M.G.; Orleanskaya, O.B. Physiological characteristics of Chlorella sp. K under conditions of high extremal temperatures I. Uncoupling effect of extreme temperatures on the cellular functions of Chlorella. Russian J. Plant Physiol. $1967,14,612-625$.

9. Šetlík, I.; Zachleder, V.; Doucha, J.; Berková, E.; Bartoš, J. The nature of temperature block in the sequence of reproductive processes in Chlorella vulgaris BEIJERINCK. Arch. Hydrobiol. Algol. Stud. 1975, 14, 70-104.

10. Torres-Romero, I.; Kong, F.; Legeret, B.; Beisson, F.; Peltier, G.; Li-Beisson, Y. Chlamydomonas cell cycle mutant crcdc5 overaccumulates starch and oil. Biochimie 2019. [CrossRef]

11. Lacour, T.; Sciandra, A.; Talec, A.; Mayzaud, P.; Bernard, O. Neutral lipid and carbohydrate productivities as a response to nitrogen status in Isochrysis sp. (T-iso; Haptophyceae): Starvation vs. limitation. J. Phycol. 2012, 48, 647-656. [CrossRef]

12. Ball, S.G.; Dirick, L.; Decq, A.; Martiat, J.C.; Matagne, R.F. Physiology of starch storage in the monocellular alga Chlamydomonas reinhardtii. Science 1990, 66, 1-9. [CrossRef]

13. Burlacot, A.; Peltier, G.; Li-Beisson, Y. Subcellular energetics and carbon storage in Chlamydomonas. Cells 2019, 8, 1154. [CrossRef] [PubMed]

14. Chen, H.; Hu, J.; Qiao, Y.; Chen, W.; Rong, J.; Zhang, Y.; He, C.; Wang, Q. Ca ${ }^{2+}$-regulated cyclic electron flow supplies ATP for nitrogen starvation-induced lipid biosynthesis in green alga. Sci. Rep. 2015, 5, 15117. [CrossRef]

15. Peltier, G.; Schmidt, G.W. Chlororespiration: An adaptation to nitrogen deficiency in Chlamydomonas reinhardtii. Proc. Natl. Acad. Sci. USA 1991, 88, 4791-4795. [CrossRef]

16. Salome, P.A.; Merchant, S.S. A series of fortunate events: Introducing Chlamydomonas as a reference organism. Plant Cell 2019. [CrossRef] [PubMed]

17. Sasso, S.; Stibor, H.; Mittag, M.; Grossman, A.R. From molecular manipulation of domesticated Chlamydomonas reinhardtii to survival in nature. eLife 2018, 7, e39223. [CrossRef] [PubMed]

18. Zhang, M.-P.; Wang, M.; Wang, C. Nuclear transformation of Chlamydomonas reinhardtii: A review. Biochimie 2021, 181, 1-11. [CrossRef] [PubMed]

19. Koo, K.M.; Jung, S.; Lee, B.S.; Kim, J.B.; Jo, Y.D.; Choi, H.I.; Kang, S.Y.; Chung, G.H.; Jeong, W.J.; Ahn, J.W. The mechanism of starch over-accumulation in Chlamydomonas reinhardtii high-starch mutants identified by comparative transcriptome analysis. Front. Microbiol. 2017, 8, 858. [CrossRef] [PubMed]

20. Gifuni, I.; Olivieri, G.; Pollio, A.; Franco, T.T.; Marzocchella, A. Autotrophic starch production by Chlamydomonas species. J. Appl. Phycol. 2016, 29, 105-114. [CrossRef]

21. Schulz-Raffelt, M.; Chochois, V.; Auroy, P.; Cuiné, S.; Billon, E.; Dauvillée, D.; Li-Beisson, Y.; Peltier, G. Hyper-accumulation of starch and oil in a Chlamydomonas mutant affected in a plant-specific DYRK kinase. Biotechnol. Biofuels 2016, 9, 55. [CrossRef]

22. Mathiot, C.; Ponge, P.; Gallard, B.; Sassi, J.F.; Delrue, F.; Le Moigne, N. Microalgae starch-based bioplastics: Screening of ten strains and plasticization of unfractionated microalgae by extrusion. Carbohydr. Polym. 2019, 208, 142-151. [CrossRef]

23. Sueoka, N. Mitotic replication of deoxyribonucleic acid in Chlamydomonas reinhardtii. Proc. Natl. Acad. Sci. USA 1960, 46, 83-91. [CrossRef]

24. Miller, G.L. Use of dinitrosalicylic acid reagent for determination of reducing sugar. Anal. Chem. 1959, 31, 426-428. [CrossRef]

25. Fernandes, B.; Teixeira, J.; Dragone, G.; Vicente, A.A.; Kawano, S.; Bišová, K.; Přibyl, P.; Zachleder, V.; Vítová, M. Relationship between starch and lipid accumulation induced by nutrient depletion and replenishment in the microalga Parachlorella kessleri. Bioresour. Technol. 2013, 144, 268-274. [CrossRef]

26. Siaut, M.; Cuine, S.; Cagnon, C.; Fessler, B.; Nguyen, M.; Carrier, P.; Beyly, A.; Beisson, F.; Triantaphylides, C.; Li-Beisson, Y.; et al. Oil accumulation in the model green alga Chlamydomonas reinhardtii: Characterization, variability between common laboratory strains and relationship with starch reserves. BMC Biotechnol. 2011, 11, 7. [CrossRef] [PubMed]

27. Nitsos, C.; Filali, R.; Taidi, B.; Lemaire, J. Current and novel approaches to downstream processing of microalgae: A review. Biotechnol. Adv. 2020, 45, 107650. [CrossRef] [PubMed]

28. Gifuni, I.; Pollio, A.; Marzocchella, A.; Olivieri, G. New ultra-flat photobioreactor for intensive microalgal production: The effect of light irradiance. Algal Res. 2018, 34, 134-142. [CrossRef]

29. Carvalho, A.P.; Silva, S.O.; Baptista, J.M.; Malcata, F.X. Light requirements in microalgal photobioreactors: An overview of biophotonic aspects. Appl. Microbiol. Biotechnol. 2011, 89, 1275-1288. [CrossRef] [PubMed] 
30. Murphy, T.E.; Berberoğlu, H. Effect of algae pigmentation on photobioreactor productivity and scale-up: A light transfer perspective. J. Quant. Spectrosc. Radiat. Transf. 2011, 112, 2826-2834. [CrossRef]

31. Li, T.; Wang, W.; Yuan, C.; Zhang, Y.; Xu, J.; Zheng, H.; Xiang, W.; Li, A. Linking lipid accumulation and photosynthetic efficiency in Nannochloropsis sp. under nutrient limitation and replenishment. J. Appl. Phycol. 2020, 32, 1619-1630. [CrossRef]

32. Huang, Q.; Jiang, F.; Wang, L.; Yang, C. Design of photobioreactors for mass cultivation of photosynthetic organisms. Engineering 2017, 3, 318-329. [CrossRef] 